\title{
PENGEMBANGAN MODUL SOFTWARE MULTIMEDIA INTERAKTIF DENGAN STRATEGI PEMBELAJARAN BERBASIS MASALAH UNTUK MENINGKATKAN PEMAHAMAN KONSEP DAN HASIL BELAJAR FISIKA SISWA KELAS XII SMA
}

\author{
I Nyoman P Suwindra ${ }^{1}$, Rai Sujanem ${ }^{2}$, Iwan Suswandi ${ }^{3}$ \\ 1, 2, 3 Jurusan Pendidikan Fisika FMIPA, Universitas Pendidikan Ganesha \\ Singaraja, Indonesia \\ e-mail: indranetmail@yahoo.com
}

\begin{abstract}
Abstrak
Penelitian ini bertujuan untuk: (1) mengembangkan modul fisika multimedia interaktif, (2) menjelaskan perbedaan pengaruh antara belajar dengan modul multimedia (MPMM) dan model pembelajaran konvensional (MPK) terhadap pemahaman konsep, dan (3) menjelaskan perbedaan pengaruh antara MPMM dan MPK terhadap hasil belajar fisika siswa kelas XII SMA. Untuk mencapai tujuan tersebut dilakukan penelitian dalam dua tahapan, yaitu: pengembangan modul dan eksperimen. Data dikumpulkan dengan tes, angket, wawancara. Data yang terkumpul dianalisis secara statistik deskriptif dan multivariat. Hasil penelitian diperoleh sebagai berikut. (1) Terdapat perbedaan pemahaman konsep antara kemompok belajar dengan MPMM dan kelompok belajar dengan MPK $(F=250,602 ; p<0,05)$. Nilai rata-rata pemahaman konsep kelompok siswa yang belajar dengan MPMM lebih tinggi daripada yang belajar dengan MPK $(\Delta \mu=10,831 ; \mathrm{SD}=0,684$; $\mathrm{p}<0,05)$. (2) Terdapat perbedaan hasil belajar fisika antara belajar dengan MPMM dan belajar dengan MPK $(F=385,237 ; p<0,05)$. Nilai rata-rata hasil belajar siswa kelompok belajar dengan MPMM lebih tinggi daripada kelompok belajar dengan MPK $(\Delta \mu=11,555$; $\mathrm{SD}=0,589 ; \mathrm{p}<0,05)$. Berdasarkan analisis respon, siswa memberi respon postif terhadap modul. Oleh karena itu, modul fisika multimedia interaktif layak dan efektif untuk meningkatkan pemahaman konsep dan hasil belajar siswa.
\end{abstract}

Kata Kunci: Modul fisika, multimedia interaktif, pemahaman konsep. 


\begin{abstract}
This study aims to: (1) develop interactive multimedia physics module, (2) explain the difference in effect between learning with multimedia modules (MPMM) and conventional learning model (MPK) to the understanding of concepts, and (3) explain the difference in effect between MPMM and MPK against the results of class XII student studying physics in high school. To achieve these objectives the research conducted in two phases, namely: the development of modules and experiments. Data collected by the test, questionnaire, interview. The collected data were analyzed by descriptive and multivariate statistics. The results obtained as follows. (1) There is a difference between groups MPMM understanding of concepts and MPK group ( $F=F=250.602 ; p<0.05)$. The average value of understanding concept of groups of students who studied with MPMM higher than those studied by MPK $(\Delta \mu=10.831 ; S D=0.684 ; p<0,05)$. (2) There is a difference between learning the results of studying physics with MPMM and learn with MPK $(F=385.237 ; p<0.05)$. The average value of student learning outcomes, study groups with MPMM is higher than study groups with MPK $(\Delta \mu=11.555 ; S D=0.589 ; p<0,05)$. Based on the responses analysis, students responded positively towards the module. Therefore, interactive multimedia physics module feasible and effective to improve the understanding of concepts and student learning outcomes.
\end{abstract}

Keywords: physics module, interactive multimedia, conceps understanding.

\section{PENDAHULUAN}

Masalah yang melanda dunia pendidikan fisika sebagian besar berkutat di sekitar upaya meningkatkan pemahaman konsep oleh siswa. Pemahaman konsep dan hasil belajar fisika siswa, khusus siswa SMA dalam belajar fisika masih relatif rendah, karena pengemasan pendidikan sering tidak sejalan dengan hakekat belajar dan mengajar fisika (Degeng dalam Santyasa, et al.,2005; Brook \& Brook, 1993). Untuk itu perlu dirancang pengemasan pendidikan yang sejalan dengan hakekat belajar dan mengajar yakni: bagaimana siswa belajar, bagaimana guru mengajar, bagaimana pesan pembelajaran di dalam bahan ajar itu, bukan semata-mata pada hasil belajar (Brook \& Brook, 1993, Lawson, 1998, Novak, 1985).

Fisika sebagai bagian dari Sains adalah ilmu pengetahuan alam yang menjelaskan fenomena teramati (observable) dengan model-model. Modelmodel ini didasarkan pada pengalaman manusia, pikiran rasional, dan eksperimen secara detail. Jastifikasi model-model (konsep, hukum, teori-teori) didasarkan pada bukti eksperimen dan konsesus dalam komunitas penelitian. Selama proses belajar ini, siswa membuat teori, konsep, instrumen, dan mengaplikasikannya dalam kehidupan nyata. Hampir semua aspek kehidupan manusia dewasa ini dikelilingi oleh masalahmasalah yang mengandung implikasiimplikasi ilmiah. Pada sisi lain, pendidikan fisika di sekolah selama ini kurang dikaitkan dengan masalah-masalah nyata yang ada di seputar siswa seperti masalah krisis energi, efek rumah kaca, polusi udara, masalah yang ditimbulkan oleh petir, masalah kebakaran gedung akibat korsleting, masalah saluran listrik tegangan tinggi (sutet), dan sebagainya. Di samping itu, pembelajaran fisika sekarang ini kurang membangun pemahaman siswa. Bagi para pendidik, pemahaman jauh lebih penting daripada prestasi yang diukur dengan skor tes (Brook \& Brook, 1993). Masalah besar yang dihadapi dunia pendidikan pada saat ini masih berkutat pada masalah 
pemahaman dan miskonsepsi (Brook \& Brook, 1993, Sadia, et al., 2005; Suparno, 2005; Santyasa, et al., 2005).

Pengemasan modul atau bahan ajar fisika selama ini masih bersifat linier, yaitu: materi ajar yang hanya menyajikan konsep dan prinsip, contoh-contoh soal dan pemecahannya, dan soal-soal latihan. Untuk itu perlu diimplementasikan kemasan modul fisika yang konseptual dan kontekstual yang mengintegrasikan kearifan lokal dan teknologi. Pengintegrasian kearifan lokal dalam pembelajaran Fisika sejalan dengan acuan operasional penyusunan KTSP, yang menyebutkan agar kurikulum disusun dengan memperhatikan kondisi sosial budaya masyarakat setempat untuk menunjang kelestarian keragaman budaya, penghayatan dan apresiasi budaya sendiri sebelum mempelajari budaya lain (BSNP, 2006).

Perkembangan teknologi informasi dan komunikasi atau information and technology communication (ICT), baik komputer maupun internet memberi peluang dunia pendidikan untuk mengakses berbagai informasi baik berbentuk teks, gambar, simulasi, maupun suara (Hardjito, 2005, Siahaan, 2002). Pengemasan materi dalam bentuk modul program software yang mengkombinasikan antara video dan audio, yang meliputi: cuplikan film tentang penomena/masalah di lingkungan kehidupan siswa, teks yang dapat merangsang siswa berpikir untuk memahami konsep, simulasi yang mempu meningkatkan pemikiran sbstrak siswa, akan menjadi alternatif bagi siswa dalam mengembangkan cara belajar mandiri bagi siswa. Hasil pengemasan program software tersebut selanjutnya disebut sebagai Modul Software Multimedia Interaktif. Modul program software multimedia tersebut nantinya dapat disimpan di dalam hardisk PC, sehingga di rumah siswa dapat membuka setiap saat dibutuhkan. Bagi siswa yang memiliki laptop, modul juga dapat disimpan di laptopnya, sehingga dapat dibawa kemana siswa pergi dan mempelajari kembali bila dibutuhkan. Di samping itu, dengan perkembangan ICT yang telah memasuki berbagai bidang kehidupan termasuk dunia pendidikan, program modul software multimedia interaktif tersebut dapat dikemas dalam arsip e-book dalam bentuk winzip atau winrar, selanjutnya disimpan di sebuah website atau blog, sehingga modul tersebut dapat diakses oleh siapa saja, darimana dan kapan saja sesuai kehendak dan kebutuhan mereka.

Pengintegrasian ICT dalam dunia pendidikan, khususnya berkaitan dengan kemasan pembelajaran berbantuan modul program software multimedia interaktif dengan strategi pembelajaran berbasis masalah, membawa revolusi baru dan memberi peluang pencapaian pemahaman dan hasil belajar yang lebih tinggi (IHEP, dalam Oliver, 2002, Vescoukis, et.al dalam Retalis, 2001, Duffy \& Cunningham, 1996, Jonassen, dalam Liu, 2005, Willian, et al, 1998).

Di balik manfaatnya yang besar dalam pembelajaran web, internet dirasa masih cukup mahal terutama dalam hal saluran komunikasi. Berdasarkan kondisi ini perlu dikembangkan program modul pembelajaran berupa software multimedia interaktif yang memberikan flesibelitas dalam pemanfaatan media tersebut, karena siswa maupun guru tidak mesti harus mengaskes melalui internet, tetapi dapat di dalam PC atau pun laptop, kecuali bagi yang belum memiliki program modul software tersebut. Dalam penelitian ini,

Jurnal Pendidikan Indonesia | 15 
modul multimedia interaktif yang dikembangkan disimpan dan diperbanyak dalam bentuk CD program.

Tujuan penelitian ini adalah untuk menghasilkan modul fisika multimedia interaktif yang teruji kelayakannya untuk fasilitas belajar bagi siswa kelas X SMA. Target khusus yang ingin dicapai, yaitu menguji keunggulan komparatif antara modul yang dikembangkan dan strategi pembelajaran terhadap pemerolehan pemahaman dan hasil belajar siswa.

Pandangan konstruktivisme mengatakan bahwa pengetahuan itu dibangun dalam pikiran siswa. Siswa sendirilah yang harus aktif secara mental membangun pengetahuannya lewat transformasi pengalaman-pengalaman yang diperolehnya baik secara informal dan formal. Dari sudut pandang ini ternyata pengalaman memiliki peranan sentral dalam proses belajar seseorang, karena pada hakekatnnya refleksi terhadap pengalaman merupakan proses belajar yang alami. Aktivitas terpusat pada siswa (Students centered).

Menurut Gardner, dan Wilis (dalam Santyasa, 2003) seseorang dikatakan memahami apabila dia dapat menunjukkan unjuk kerja pemahaman tersebut pada level kemampuan yang lebih tinggi baik pada konteks yang sama maupun pada konteks yang berbeda. Lebih lanjut Yulaelawaty (2002) mengungkapkan bahwa pemahaman merupakan perangkat baku program pendidikan yang merefleksikan kompetensi, sehingga dapat mengantarkan siswa menjadi kompeten dalam berbagai bidang kehidupan. Dengan demikian, pemahaman merupakan salah satu unsur pendidikan yang mendasar dalam rangka mencapai tujuan pendidikan.
Dengan semakin canggihnya perkembangan teknologi komputer, saat telah dapat disusun sebuah software pembelajaran yang mampu mengakomodir tiga modalitas utama yaitu visual, audio, dan kinestesis. Software multimedia interaktif adalah software yang memiliki kelebihan dapat mengakomodir hal tersebut. Secara sederhana, multimedia dapat diartikan sebagai lebih dari satu media (Arsyad, 2005). Multimedia bisa berupa kombinasi antara teks, grafik, suara, video, dan animasi. Pemanfaatan multimedia dalam pembelajaran berdasarkan asumsi bahwa dalam proses komunikasi pembelajaran akan lebih baik apabila dapat digunakan sebagai media sesuai dengan karakteristik dari multimedia tersebut. Multimedia bertujuan untuk menyajikan informasi dalam bentuk yang menyenangkan, menarik, mudah dimengerti, dan jelas (Arsyad, 2005). Software pembelajaran multimedia interaktif adalah media pembelajaran yang merupakan kombinasi dari berbagai unsur media yang terdiri dari teks, grafis, foto, animasi, video, dan suara yang disajikan secara interaktif (Koesnandar, 2006). Informasi yang disajikan melalui multimedia ini berbentuk dokumen yang hidup, dapat dilihat di layar monitor, dan dapat didengar suaranya, dilihat gerakannya berupa video atau animasi (Arsyad, 2005).

Beberapa kemampuan software pembelajaran fisika multimedia interaktif antara lain (1) dapat memberikan informasi secara audio-video serta interaktif sehingga mampu mengakomodir pengguna (siswa) dengan gaya belajar yang beraneka ragam (2) mampu menampilkan berbagai macam demonstrasi fisika, demonstrasi yang dilakukan lebih bersifat mudah, mengurangi kesulitan dalam penyiapan alat, dan mengatasi kelemahan kesalahan alat; (3)

Jurnal Pendidikan Indonesia | 16 
mampu mensimulasikan berbagai konsepkonsep fisika termasuk konsep-konsep yang unobservable dalam bentuk audio video sehingga menciptakan suasana belajar yang lebih nyata; (4) praktis karena berupa software komputer yang dapat disimpan dalam sebuah compact disk sehingga dapat digunakan di mana saja dan kapan saja; dan (5) mampu menciptakan animasianimasi maupun tampilan-tampilan menarik lainnya serta permainan sehingga menumbuhkan minat siswa dalam mempelajari fisika.

$$
\text { Kajian berbagai literatur }
$$

menunjukkan pembelajaran dengan strategi PBL dapat meningkatkan ketrampilan berpikir siswa. Teknologi dapat digunakan untuk memfasilitasi belajar, bagaimana guru memanfaatkan alat tersebut biar memiliki nilai yang optimal, khususnya dalam pemanfaatn animasi komputer dalam pembelajaran. Meskipun animasi komputer secara teoritik baik untuk belajar maupun asesemen, komputer hanya dipahami bagaimana penggunaan yang terbaik. Animasi akan menyediakan potensi untuk meningkatkan belajar bila diperlukan untuk visualisasi eksternal dan isi bergantung pada pemahaman. Animasi dapat dipergunakan untuk menunjukkan situasi yang lebih meyakinkan dalam kemampuan siswa memahami daripada tulisan atau grafik. jadi, animasi dapat sangat membantu dalam memberi peluang untuk siswa bertanya dan memahami dan merupakan alat asesmen yang efektif. Siswa lebih sulit menginterpretasi grafik atau gambar statik dibandingkan dengan gambar animasi. Sebuah animasi memberikan lebih banyak informasi dibandingkan dengan obyek statik atau deskripsi gerak, karena animasi menunjukkan semua aspek gerak pada setiap saat. Hasil penelitian menunjukkan bahwa animasi dapat digunakan untuk meningkatkan validitas asesmen. Melihat kemampuan tersebut maka, secara teoretis penggunaan modul fisika multimedia interaktif akan membantu siswa dalam membangun pemahaman konsep-konsep fisika dengan waktu yang efisien. Oleh karena itu penggunaan modul fisika multimedia interaktif dalam pembelajaran fisika SMA akan mampu meningkatkan pemahaman dan hasil belajar fisika siswa.

\section{METODE}

Penelitian ini menggunakan desain pretes-postest control group design dengan 2 perlakuan. Pada masing-masing perlakuan ditetapkan 50 subjek untuk model 1 , dan 60 subjek untuk model 2, sehingga unit analisis keseluruhan adalah 110 baik pada hasil pretes maupun pada hasil postes.

Subjek penelitian ini adalah Siswa, Guru Fisika, Guru TIK SMA Negeri di Kabupaten Buleleng. Peran Guru Fisika dan TIK adalah sebagai berikut: (1) Guru Fisika memberikan informasi tentang proses pembelajaran yang dilakukan selama ini, kesulitan-kesulitan yang dialami dalam menjelaskan konsep, kesulitan siswa secara umum dalam pemahaman konsep, memberikan masukan tentang media yang dikembangkan, dan menerapkan media bagi guru di sekolah yang ditetapkan sebagai sampel penelitian. (2) Guru TIK memberikan informasi tentang keberadaan fasilitas TIK yang ada di sekolah, serta efektivitas penggunaan Lab Komputer yang ada di sekolahnya.

Objek atau aspek-aspek yang diteliti, meliputi: (1) Pengetahuan awal dan miskonsepsi siswa. (2) Modul multimedia interaktif. (3) Pemahaman konsep dan hasil belajar fisika siswa. Penelitian dilakukan 
dalam dua tahap, yaitu: tahap pengembangan modul dan tahap eksperimen.

Data yang terkumpul dianalisis secara statistik deskriptif dan analisis covarian multivariate (Montgomery, 1984; Santoso, 2002, Winer, 1971), dengan mengggunakan program SPSS 13.0 for windows.

\section{HASIL PENELITIAN}

\section{Deskripsi Hasil Pengembangan Modul}

Modul software multimedia fisika interaktif, dikembangkan mengacu pada hasil análisis kebutuhan. Data yang diperoleh dari guru fisika, TIK, maupun siswa di sekolah digunakan sebagai dasar untuk merancang desain dari modul multimedia. Pendesainan dan pemrograman dilakukan untuk modul semester 1 dan 2 di kelas XI SMA.

Validasi modul meliputi: uji validasi isi, dan uji validasi media. Berdasarkan koreksi dan rekomendasai dari ahli isi, ahli media, selanjutnya dilakukan revisi. Sebelum dilakukan uji coba dilakukkan pelatihan penggunaan modul terhadap guruguru, sekaligus untuk memperoleh masukan dari para guru. Selanjutnya modul diujicobakan secara terbatas pada tahap eksperimen/ujicoba terbatas.

Uji coba terbatas dilakukan terhadap sekolah yang ditetapkan sebagai tempat uji coba. Uji coba dilakukan di SMA Negeri 1 Busungbiu sebagai sekolah eksperimen (Model 1), dengan jumlah sampel 60 orang, dan SMA Negeri 1 Sukasada sebagai sekolah kontrol (Model 2) dengan jumlah sampel 50 orang. Materi modul multimedia yang diujicobakan adalah materi di semester ganjil terfokus pada pokok bahasan Medan listrik dan Medan Magnet. Media dalam bentuk CD diberikan kepada guru sesuai dengan jumlah komputer yang tersedia di sekolahnya. Sebelum proses pembelajaran guru-guru, yang terlibat diberikan pelatihan berdasarkan pedoman penggunaan modul multimedia yang telah dibuat.

\section{Deskripsi Umum Hasil Analisis Data}

Deskripsi umum yang dipaparkan pada bagian ini meliputi: (1) deskripsi nilai rata-rata $(M)$ dan simpangan baku (SD) pemahaman konsep dan hasil belajar yang diperoleh dari hasil pretes, dan (2) deskripsi nilai rata-rata (M) dan simpangan baku (SD) pemahaman konsep, dan hasil belajar yang diperoleh dari hasil postes.

Data pemahaman konsep diperoleh dari tes pemahaman konsep dan data hasil belajar diperoleh dari tes hasil belajar. Tes pemahaman konsep terdiri dari 15 butir soal, dan tes hasil belajar terdiri dari 30 butir soal. Skor minimal dari masing-masing butir tes adalah 0 (nol), skor maksimal adalah 4, dan skor masksimal tes hasil belajar 5 . Selanjutnya skor dikonversi ke skala 100.

Deskripsi umum nilai rata-rata dan simpangan baku data pemahaman konsep dan hasil belajar menggunakan pedoman konversi nilai absolut skala lima. Jika skor rata-rata pemahaman konsep siswa adalah 0-16,5 berarti sangat kurang, 16,6-33,2 berarti kurang, 33,3-67,6 berarti cukup, 67,7-83,3 berarti baik, dan skor 83,4-100 berarti sangat baik.

(1) Deskripsi nilai rata-rata dan standar deviasi hasil prates

Sebelum pembelajaran diterapkan diberikan tes awal, baik tes pemahaman konsep maupun tes hasil belajar. Hasil ratarata dan stándar deviasi, seperti terlihat seperti tabel berikut ini. 
Tabel 1. Nilai rata-rata (M) dan Stándar Deviasi (SD) Prates

\begin{tabular}{|rl|r|r|r|}
\hline & Model & Mean & Std. Deviation & \multicolumn{1}{|c|}{$\mathrm{N}$} \\
\hline PraPK & 1 & 36,092 & 5,0525 & 60 \\
& 2 & 34,800 & 4,5070 & 50 \\
& Total & 35,505 & 4,8339 & 110 \\
\hline PraHB & 1 & 35,098 & 3,6013 & 60 \\
& 2 & 34,381 & 3,7378 & 50 \\
& Total & 34,772 & 3,6646 & 110 \\
\hline
\end{tabular}

Model pembelajaran: (1) Model Pembelajaran Modul Software Multimedia (MPMM), dan (2) Model Pembelajaran Konvensional (MPK). PraPK = Pemahaman Konsep awal, dan PraHB = Hasil Belajar awal. Berdasarkan Tabel 1, tampak bahwa nilai rata-rata pemahaman konsep (PK) dan hasil belajar (HB) berada pada kualifikasi cukup. Hal ini terlihat dari nilai rata-rata (M) dan standard deviasi (SD) masing-masing kelompok adalah: (1) pemahaman konsep (PK), $M=36,0092$ dan $\mathrm{SD}=5,0525$ untuk kelompok MPMM serta $\mathrm{M}=34,800$ dan $\mathrm{SD}=$ 4,5070 untuk kelompok MPK; (2) hasil belajar (HB), $\mathrm{M}=35,098$ dan $\mathrm{SD}=3,6013$ untuk kelompok MPMM serta $\mathrm{M}=34,381$ dan $\mathrm{SD}=3,7378$ untuk kelompok MPK. Hal ini menunjukkan sebelum diberi perlakuan, PK dan HB kedua kelompok tampak setara.

(2) Deskripsi nilai rata-rata dan standar deviasi hasil Pascates

Setelah pembelajaran diterapkan diberikan tes akhir, baik tes pemahaman konsep maupun tes hasil belajar. Hasil ratarata dan stándar deviasi, seperti terlihat seperti tabel berikut ini.

Tabel 2. Nilai rata-rata (M) dan Stándar Deviasi (SD) Pancates

\begin{tabular}{|ll|c|r|r|}
\hline & Model & Mean & Std. Deviation & \multicolumn{1}{c|}{ N } \\
\hline PK & 1 & 52,084 & 3,7479 & 60 \\
& 2 & 41,533 & 3,6708 & 50 \\
& Total & 47,288 & 6,4432 & 110 \\
\hline $\mathrm{HB}$ & 1 & 52,874 & 3,3831 & 60 \\
& 2 & 41,482 & 3,0594 & 50 \\
& Total & 47,696 & 6,5481 & 110 \\
\hline
\end{tabular}

Model pembelajaran: (1) Model Pembelajaran Modul Software Multirmedia (MPMM), dan (2) Model Pembelajaran Konvensional (MPK). PK= Pemahaman Konsep, dan $\mathrm{HB}=$ Hasil Belajar. Berdasarkan Tabel 2 tampak bahwa nilai rata-rata $(\mathrm{M})$ pemahaman konsep (PK) untuk setiap kelompok pembelajaran, $\mathrm{M}=52,084$ dan $\mathrm{SD}=3,7479$ untuk kelompok
MPMM serta $M=41,533$ dan $S D=3,6708$ untuk kelompok MPK, masing-masing masih berkualifikasi cukup. Demikian juga untuk nilai rata-rata $(\mathrm{M})$ hasil belajar fisika (HB) setiap kelompok model pembelajaran, $\mathrm{M}=52,874$ dan $\mathrm{SD}=3,3831$ untuk kelompok MPMM serta $M=41,482$ dan $S D=3,0594$ untuk kelompok MPK, masing-masing berkualifikasi cukup. Dilihat dari nilai rata- 
rata $(\mathrm{M})$, tampak secara deskriptif kelompok MPMM relatif lebih baik dari kelompok MPK.

\section{Hasil Uji Hipotesis Penelitian}

Uji hipótesis penelitan dilakukan dengan análisis multivariat (MANCOVA). Sebelum uji multivariat, dilakukan uji normalitas sebaran data setiap variabel dan homogenitas variansinya. Uji normalitas dan homogenitas masing-masing menggunakan statistik KolmogorovSmirnov test maupun Shapiro-Wilk dan statistik Levene of equality of error variance. Hasil uji menunjukkan data berdistribusi nornal dan variansinya homogen.

\section{(a) Uji Multivariat}

MANCOVA bermaksud untuk meneliti pengaruh masing-masing variabel bebas termasuk kovariat terhadap variabel terikat secara bersama-sama. Hasil analisis tersebut disajikan pada Tabel 3. Berdasarkan hasil uji multivariat dapat ditarik interpretasi-interpretasi sebagai berikut.

Pertama, dari pengaruh kovariat PraPK ditemukan bahwa nilai-nilai statistik Pillai's Trace, Wilks' Lamda, Hotelling's
Trace, Roy's Largest Root masing-masing dengan $F=8,592$ dan angka signifikansi masing-masing 0,000. Semua angka signifikansi ini lebih kecil dari 0,05. Jadi, secara bersama-sama pemahaman konsep dan hasil belajar secara signifikan $(p<0,05)$ dipengaruhi oleh kovariat pemahaman konsep awal. Dengan kata lain, terdapat perbedaan pemahaman konsep, dan hasil belajar untuk berbagai tingkatan pemahaman konsep awal.

Kedua, pengaruh kovariat PraHB ditemukan bahwa nilai-nilai statistik Pillai's Trace, Wilks' Lamda, Hotelling's Trace, Roy's Largest Root masing-masing dengan $F=5,276$ dan angka signifikansi masingmasing 0,007 . Semua angka signifikansi ini lebih kecil dari 0,05. Jadi, secara bersamasama pemahaman konsep dan hasil belajar secara signifikan $(p<0,05)$ dipengaruhi oleh kovariat hasil belajar awal. Dengan kata lain, terdapat perbedaan pemahaman konsep, dan hasil belajar untuk berbagai tingkatan hasil belajar awal.

Tabel 3. Ringkasan hasil uji multivariate

\begin{tabular}{|ll|r|r|r|r|r|}
\hline Effect & & \multicolumn{1}{|c|}{ Value } & \multicolumn{1}{c|}{ F } & Hypothesis df & Error df & \multicolumn{1}{c|}{ Sig. } \\
\hline Intercept & Pillai's Trace &, 754 & $160,648^{\mathrm{a}}$ & 2,000 & 105,000 &, 000 \\
& Wilks' Lambda &, 246 & $160,648^{\mathrm{a}}$ & 2,000 & 105,000 &, 000 \\
& Hotelling's Trace & 3,060 & $160,648^{\mathrm{a}}$ & 2,000 & 105,000 &, 000 \\
& Roy's Largest Root & 3,060 & $160,648^{\mathrm{a}}$ & 2,000 & 105,000 &, 000 \\
\hline PraPK & Pillai's Trace &, 141 & $8,592^{\mathrm{a}}$ & 2,000 & 105,000 &, 000 \\
& Wilks' Lambda &, 859 & $8,592^{\mathrm{a}}$ & 2,000 & 105,000 &, 000 \\
& Hotelling's Trace &, 164 & $8,592^{\mathrm{a}}$ & 2,000 & 105,000 &, 000 \\
& Roy's Largest Root &, 164 & $8,592^{\mathrm{a}}$ & 2,000 & 105,000 &, 000 \\
\hline PraHB & Pillai's Trace &, 091 & $5,276^{\mathrm{a}}$ & 2,000 & 105,000 &, 007 \\
& Wilks' Lambda &, 909 & $5,276^{\mathrm{a}}$ & 2,000 & 105,000 &, 007 \\
& Hotelling's Trace &, 100 & $5,276^{\mathrm{a}}$ & 2,000 & 105,000 &, 007 \\
& Roy's Largest Root &, 100 & $5,276^{\mathrm{a}}$ & 2,000 & 105,000 &, 007 \\
\hline Model & Pillai's Trace &, 796 & $204,412^{\mathrm{a}}$ & 2,000 & 105,000 &, 000 \\
& Wilks' Lambda &, 204 & $204,412^{\mathrm{a}}$ & 2,000 & 105,000 &, 000 \\
& Hotelling's Trace & 3,894 & $204,412^{\mathrm{a}}$ & 2,000 & 105,000 &, 000 \\
& Roy's Largest Root & 3,894 & $204,412^{\mathrm{a}}$ & 2,000 & 105,000 &, 000 \\
\hline
\end{tabular}




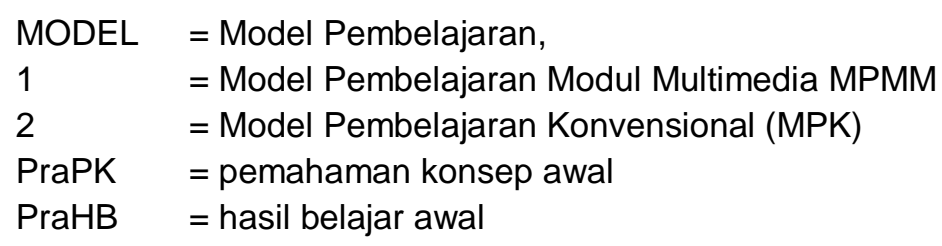

Ketiga, ditinjau dari sumber pengaruh variabel bebas model-model pembelajaran diperoleh nilai-nilai statistik Pillai's Trace, Wilks' Lamda, Hotelling's Trace, Roy's Largest Root masing-masing dengan $F=204,412$ dan angka signifikansi masing-masing 0,000 . Semua angka signifikansi ini lebih kecil dari $0,05(p<0,05)$, maka perbedaan model pembelajaran akan memberikan hasil yang berbeda serempak pada semua variabel terikat. Model MPMM memberikan hasil yang lebih tinggi untuk pemahaman konsep dan hasil belajar dibandingkan model MPK. (b) Pengujian Hipotesis

Dalam penelitian ada 2 hipotesis yang akan diuji. Pengujian dilakukan terhadap hipotesis nol. Hipotesis-hipotesis nol yang diuji adalah sebagai berikut. (1) Tidak terdapat perbedaaan pemahaman konsep (PK) antar kelompok siswa yang belajar menggunakan MPMM dan MPK. (2) Tidak terdapat perbedaaan hasil belajar (HB) antar kelompok siswa yang belajar menggunakan MPMM dan MPK. Untuk menguji kedua hipotesis tersebut, dilakukan MANCOVA. Analisis menggunakan bantuan software SPSS 13.0 for Windows. Hasil analisis data disajikan seperti Tabel 4.

Tabel 4. MANCOVA untuk pengujian hipotesis

\begin{tabular}{|ll|r|r|r|r|r|}
\hline Source & Dependent Variable & $\begin{array}{r}\text { Type III Sum } \\
\text { of Squares }\end{array}$ & df & Mean Square & \multicolumn{1}{c|}{ F } & Sig. \\
\hline Corrected Model & PK & $3196,178^{\circ}$ & 3 & 1065,393 & 84,983 &, 000 \\
& HB & $3689,873^{\circ}$ & 3 & 1229,958 & 132,525 &, 000 \\
\hline Intercept & PK & 3084,739 & 1 & 3084,739 & 246,060 &, 000 \\
& HB & 2499,113 & 1 & 2499,113 & 269,273 &, 000 \\
\hline PraPK & PK & 149,513 & 1 & 149,513 & 11,926 &, 001 \\
& HB & 142,579 & 1 & 142,579 & 15,363 &, 000 \\
\hline PraHB & PK & 29,781 & 1 & 29,781 & 2,376 &, 126 \\
& HB & 96,927 & 1 & 96,927 & 10,444 &, 002 \\
\hline Model & PK & 3141,681 & 1 & 3141,681 & 250,602 &, 000 \\
& HB & 3575,370 & 1 & 3575,370 & 385,237 &, 000 \\
\hline Error & PK & 1328,871 & 106 & 12,537 & & \\
& HB & 983,781 & 106 & 9,281 & & \\
\hline Total & PK & 250500,201 & 110 & & & \\
& HB & 254912,626 & 110 & & & \\
\hline Corrected Total & PK & 4525,048 & 109 & & & \\
& HB & 4673,654 & 109 & & \\
\hline
\end{tabular}

MODEL = Model Pembelajaran,

$1=$ Model Pembelajaran Modul Multimedia MPMM

$2=$ Model Pembelajaran Konvensional (MPK)

PraPK = pemahaman konsep awal

PraHB = hasil belajar awal 
Berdasarkan Tabel 4, dapat ditarik interpretasi-interpretasi terhadap variabelvariabel bahwa: (1) pengaruh masingmasing kovariat terhadap kedua variabel terikat secara individual, (2) pengaruh variabel bebas terhadap pemahaman konsep dan hasil belajar. Untuk variabel pemahaman konsep (PK), dapat ditarik beberapa interpretasi sebagai berikut.

Pertama, ditinjau dari sumber pengaruh kovariat pemahaman konsep awal (PraPK) terhadap pemahaman konsep (PK), ditemukan nilai statistik $F=11,926$ dengan angka signifikansi 0,001 yang lebih keci dari 0,05 . Hasil ini menyatakan bahwa terdapat pengaruh signifikan $(p<0,05)$ kovariat PraPK terhadap pemahaman konsep.

Kedua, dilihat dari sumber pengaruh kovariat hasil belajar awal (PraHB) terhadap PK, tampak pula nilai statistik $F=2,376$ dengan angka signifikansi 0,126 yang lebih besar dari 0,05. Hasil ini menyatakan bahwa tidak terdapat pengaruh signifikan $(p<0,05)$ kovariat PraHB terhadap pemahaman konsep.

Ketiga, dari sumber pengaruh variabel model pembelajaran (Model) terhadap variabel pemahaman konsep, ditemukan nilai statistik $F=260,206$ dengan angka signifikansi 0,000 yang lebih kecil dari 0,05. Jadi, terdapat perbedaaan pemahaman konsep antar kelompok siswa yang belajar menggunakan MPMM dan MPK.

Sedangkan untuk variabel hasil belajar (HB), dapat ditarik beberapa interpretasi sebagai berikut.

Pertama, ditinjau dari sumber pengaruh kovariat pemahaman konsep awal (PraPK) terhadap hasil belajar (HB), ditemukan nilai statistik $F=15,363$ dengan angka signifikansi 0,000 yang lebih kecil dari
0,05 . Hasil ini menyatakan bahwa terdapat pengaruh signifikan $(p<0,05)$ kovariat PraPK terhadap hasil belajar.

Kedua, dilihat dari sumber pengaruh kovariat hasil belajar awal (PraHB) terhadap hasil belajar (HB), tampak nilai statistik $F=10,444$ dengan angka signifikansi 0,002 lebih kecil dari 0,05. Hasil ini menyatakan bahwa terdapat pengaruh signifikan $(p<0,05)$ kovariat PraHB terhadap hasil belajar.

Ketiga, dari sumber pengaruh variabel model pembelajaran (Model) terhadap variabel hasil belajar, ditemukan nilai statistik $F=385,237$ dengan angka signifikasi $0,000 \quad(p<0,05)$. Jadi, terdapat perbedaaan perolehan hasil belajar antar kelompok siswa yang belajar dengan MPMM dan MPK.

(c) Uji Keunggulan Komparatif Modul

Untuk mengetahui keunggulan komparatif antara MPMM dan MPEEK, dilakukan uji least significant difference (LSD). 
Tabel 5. Hasil Analisis Komparatif Mean

\begin{tabular}{|ll|r|r|r|r|}
\hline & & & \multirow{2}{*}{} & & \multicolumn{2}{|c|}{$95 \%$ Confidence Interval } \\
\cline { 5 - 7 } Dependent Variable & Model & Mean & Std. Error & Lower Bound & Upper Bound \\
\hline PK & 1 & $52,211^{\circledR}$ &, 459 & 51,301 & 53,121 \\
& 2 & $41,380^{\circledR}$ &, 503 & 40,382 & 42,378 \\
\hline HB & 1 & $52,948^{\circledR}$ &, 395 & 52,165 & 53,731 \\
& 2 & $41,393^{\circledR}$ &, 433 & 40,535 & 42,252 \\
\hline
\end{tabular}

a. Covariates appearing in the model are evaluated at the following values: PraPK = $35,505, \mathrm{PraHB}=34,772$.

Tabel 6. Hasil Analisis Perbedaan Mean antar Pasangan Model

\begin{tabular}{|c|c|c|c|c|c|c|c|}
\hline \multirow[b]{2}{*}{ Dependent Variable } & \multirow[b]{2}{*}{ (I) Model } & \multirow[b]{2}{*}{ (J) Model } & \multirow{2}{*}{$\begin{array}{c}\text { Mean } \\
\text { Difference } \\
(1-J)\end{array}$} & \multirow[b]{2}{*}{ Std. Error } & \multirow[b]{2}{*}{ Sig. $^{3}$} & \multicolumn{2}{|c|}{$\begin{array}{c}95 \% \text { Confidence Interval for } \\
\text { Difference }\end{array}$} \\
\hline & & & & & & Lower Bound & Upper Bound \\
\hline \multirow[t]{2}{*}{ PK } & 1 & 2 & $10,831^{*}$ &, 684 &, 000 & 9,475 & 12,188 \\
\hline & 2 & 1 & $-10,831^{*}$ & 684 &, 000 & $-12,188$ & $-9,475$ \\
\hline \multirow[t]{2}{*}{$\mathrm{HB}$} & 1 & 2 & $11,555^{*}$ & ,589 &, 000 & 10,387 & 12,722 \\
\hline & 2 & 1 & $-11,555^{\star}$ & .589 &, 000 & $-12,722$ & $-10,387$ \\
\hline
\end{tabular}

Based on estimated marginal means

${ }^{*}$. The mean difference is significant at the, 05 level.

a. Adjustment for multiple comparisons: Least Siqnificant Difference (equivalent to no adjustments).

Berdasarkan Tabel 6, menunjukkan bahwa perbedaan nilai rata-rata $\mathrm{PK}$ pasangan MPMM-MPK adalah $\Delta \mu_{\text {MPMM- }}$ $\operatorname{MPK}(P K)=10,831$ dengan $S D=0,684$ dan angka signifikansi 0,000 . Angka signifikansi ini lebih kecil dari 0,05. Hal ini mengindikasikan bahwa nilai rata-rata pemahaman konsep kelompok MPMM $(\mu=52,211 ; \quad S D=0,459)$ berbeda secara signifikan dengan nilai rata-rata kelompok MPK ( $\mu=41,380 ; S D=0,503$ ), seperti terlihat pada Tabel 8. Jadi, pembelajaran dengan model berbantuan modul multimedia interaktif secara komparatif lebih unggul dibandingkan dengan kelompok pembelajaran model konvensional dalam pencapaian pemahaman konsep fisika siswa kelas XII SMA Negeri di Kabupaten Buleleng. Demikian juga halnya tentang perbedaan nilai rata-rata $\mathrm{HB}$ pasangan MPMM-MPK adalah $\Delta \mu_{\text {MPMM-MPK }}(\mathrm{HB})=$ 11,555 dengan $\mathrm{SD}=0,589$ dan angka signifikansi 0,000. Angka signifikansi ini lebih kecil dari 0,05. Hal ini mengindikasikan bahwa nilai rata-rata pemahaman konsep kelompok MPMM ( $\mu=52,948 ; \quad S D=0,395)$ berbeda secara signifikan dengan nilai ratarata kelompok MPK $(\mu=41,393 ; S D=0,433)$. Jadi, pembelajaran dengan model berbatuan modul software multimedia interaktif secara komparatif lebih unggul dibandingkan dengan kelompok pembelajaran model konvensional dalam pencapaian hasil belajar fisika siswa kelas XII SMA Negeri di Kabupaten Buleleng.

\section{PEMBAHASAN}

Proses pembelajaran yang mampu membangkitkan keinginan siswa untuk belajar harus dikondisikan, misalnya dengan penyajian masalah-masalah real (kontektual) yang ada di sekitar siswa yang terkait dengan materi yang dikaji. Hal ini dimaksudkan untuk membangun 
pemahaman siswa. Pemecahan masalahmasalah kontektual yang mungkin sudah dialami siswa akan dapat menumbuhkan ketrampilan berpikir tingkat tinggi bagi siswa. Masalah-masalah kontektual tersebut dapat dikemas dalam bentuk pembelajaran media pembelajaran berupa modul. Pembelajaran berbasis modul dapat didesain dalam bentuk teks, video, atau animasi. Modul sejenis itu sering disebut dengan modul multirmedia. Modul multimedia didesain dalam bentuk teks, video atau animasi dapat dipergunakan untuk menunjukkan situasi real yang lebih meyakinkan siswa dalam memahami konsep daripada desain dalam bentuk teks cetak, gambar, atau grafik dalam desain konvensional. Fenomena yang berhubungan dengan kehidupan masyarakat di lingkungan dimana siswa itu berada akan lebih memudahkan pemahaman siswa belajar terhadap konsep fisis yang sedang mereka pelajari. Siswa sebaiknya sudah mengenal fenomena real yang dialami. Misalnya, siswa akan lebih mudah menjelaskan konsep gerak dengan memberi contoh gerak sepeda motor daripada gerak kereta api. Dengan modul multimedia dapat memberi peluang kepada siswa untuk memfasilitasi siswa bertanya dan memahami konsep, serta merupakan alat komunikasi yang efektif. Sebuah animasi memberikan lebih banyak informasi dibandingkan dengan obyek diam atau deskripsi suatu gerakan, karena animasi menunjukkan semua aspek gerak pada setiap saat.

Berdasarkan hasil analisis data terungkap bahwa secara deskriptif pemahaman konsep dan hasil belajar siswa pada kelompok siswa yang belajar dengan multimedia (MPMM) berkatagori baik, sedangkan pada kelompok siswa belajar dengan model konvensional (MPK) berkategori cukup. Hasil uji hipotesis menunjukkan bahwa terdapat perbedaan pemahaman konsep dan hasil belajar yang signifikan antara siswa yang belajar dengan model MPMM dan model MPK. Pemahaman konsep dan hasil belajar siswa pada kelompok belajar dengan MPMM lebih tinggi dibandingkan kelompok belajar dengan MPK.

Temuan penelitian ini sejalan dengan hasil-hasil penelitian sebelumnya (Williams, et al., 1998, Suwindra, 2005, Sujanem, et al., 2007a, Sujanem, et al., 2007b) mengemukakan bahwa pemanfaatan pembelajaran ICT dapat membantu siswa lebih memahami materi pembelajaran dan meningkatkan pemahaman konsep.

Melalui pembelajaran berbantuan modul multimedia, siswa belajar dalam suatu jalinan materi yang saling kaitmengkait. Siahaan (2002) mengemukakan bahwa pembelajaran berbantuan modul multimedia memberikan peluang kepada siswa untuk memperoleh informasi yang paling mudah, cepat dan relevan sesuai materi pelajaran yang sedang dipelajari. Pembelajaran berbantuan modul multimedia juga menyediakan derajat interaktivitas yang tinggi, yang bermuara pada hasil belajar yang efektif. Pembelajaran berbantuan modul multimedia merupakan media dinamis dan tidak linier, yang konsep-konsepnya saling berkaitan dengan penuh makna dalam berbagai bentuk hubungan. Dengan sifat non linear, asosiatif, interaktif, dan kapabilitas modul multimedia menyediakan sumber yang kaya untuk mempresentasikan masalah real di dalam konteks yang real dalam menunjang belajar siswa sehingga mereka terlibat aktif dalam aktivitas kognitif yang kompleks dan pengarahan diri. Melalui modul multimedia, siswa dapat mengakses 
sumber belajar di dalam pesan atau tautan yang telah ditetapkan, dan siswa dapat melakukan navigasi pada lingkungan yang tak linear (Burton, et al, dalam Williams, et al, 1998).

Berdasarkan pembahasan tersebut, maka pembelajaran berbantuan modul multimedia dapat direkomendasikan sebagai fasilitas pembelajaran alternatif untuk mengoptimalkan pembelajaran fisika dalam pencapaian pemahaman konsep dan hasil belajar.

\section{PENUTUP}

Berdasarkan hasil penelitian dan pembahasan di atas, dapat ditarik kesimpulan sebagai berikut. (1) Terdapat perbedaan pemahaman konsep antara siswa yang menggunakan model MPMM dan yang menggunakan model MPK. Siswa yang menggunakan model MPMM menunjukkan pemahaman konsep yang lebih baik dibandingkan dengan siswa yang menggunakan model MPK. Dengan demikian, modul fisika multimedia interaktif memiliki keunggulan komparatif dibandingkan dengan model pembelajaran konvensional dalam meningkatkan pemahaman konsep fisika bagi siswa kelas XII SMA. (2) Terdapat perbedaan hasil belajar fisika antara siswa yang belajar dengan model MPMM dan yang menggunakan model MPK. Siswa yang menggunakan model MPMM menunjukkan hasil belajar fisika yang lebih baik dibandingkan dengan siswa yang menggunakan model MPK. Dengan demikian, modul fisika multimedia interaktif yang telah dikembangkan dalam penelitian ini layak, efektif, dan unggul untuk meningkatkan pemahaman konsep dan hasil belajar siswa.
Berdasarkan hasil-hasil penelitian ini, dapat diajukan saran-saran penelitian, sebagai berikut. (1) Keterampilan guru dalam menggunakan modul perlu ditingkatkan melalui pelatihan, agar bisa menyesuaikan dan membiasakan diri untuk menggunakan media dalam proses pembelajaran. (2) Pengembangan modul multimedia interaktif seperti ini perlu dilakukan untuk materi dan mata pelajaran yang lain, sehingga perkembangan TIK yang begitu pesat, dapat dimanfaatkan untuk mendukung proses pembelajaran di sekolah, karena hampir di setiap ruangan kelas disediakan LCD. (3) Fasilitas TIK yang ada di sekolah perlu ditingkatkan, karena masih ada SMA Negeri Kabupaten Buleleng yang memiliki laboratorium dengan jumlah computer yang masih terbatas.

\section{DAFTAR RUJUKAN}

Arsyad, A. 2005. Media Pembelajaran. Jakarta: PT Raja Grafindo Persada.

BSNP, 2006. Panduan Penyusunan Kurikulum Tingkat Satuan Pendidikan Jenjang Pendidikan Dasar dan Menengah. Jakarta: BSNP

Boger, S.R. \& Mechall. 1997. Cognitive Flexibility Theory: Implication for teaching and Teacher education. [Online].

http://www.eastgate.com/storyspace/ madewith/ madewith.html. Diakses tanggal 10 Pebruari 2008.

Brooks, J.G., \& Brooks,N.G.1993. In search of understanding: The case for constructivist classrooms. Virginia: Association for supervision and Curriculum Development.

Duffy, T.M. \& Cunningham,D.J. 1996. Constructism:Implication for the design and delivery for instruction. Handbook of Research for Educational Hardjito. 2005. Jurnal Internet untuk Pembelajaran, www.pustekkom.go.id. Diakses tanggal 2 Maret 2008.

Jurnal Pendidikan Indonesia | 25 
Dancy, M.H \& Beichner. R.2006. Impact of animation on assessment of conceptual understanding in physics. PHYSICAL REVIEW SPECIAL TOPIKS - PHYSICS EDUCATION RESEARCH 2, 010104 2006 hal 1-7

Koesnandar, A. 2006. Pengembangan software pembelajaran multimedia interaktif. Jurnal Teknodik. No. 18/X/TEKNODIK/Juni/2006, hal 7587. Penerbit: Pusat Teknologi Informasi dan KomPendidikan Depdiknas.

Lawson, A.E. 1998. Science Teaching and The Development of Thinking. California: Wadworth Publishing Company.

Liu, M. 2005. Alien Rescue: A ProblemBased Learning Environment for Middle School Science. http://tip.missouri.edu/tip.nsf/0/D03C1 \begin{tabular}{ll}
\hline 427DD93E76F86256 & BE7007
\end{tabular} FB59F?Open Document Diakses tanggal 2 Maret 2008.

Montgomery, D.C.1984. Design and analysis of experiment. Second Edition. New York: John Wiley \& Sons.

Nguyen, A.T.A., Tan, W., \& Kezunovic, L.1996. Interactive Multimedia on the World Wide Web: Implementation and Implications for the Tertiary Education Sector

http://ausweb.scu.edu.au/aw96/educn /nguyen/paper.htm Diakses tanggal 2 Maret 2008.

Novak, J.D. \& Gowin.D.B.1985. Learning how to learn. New York: Cambridge University Press.

Sadia,W., Suastra, I.W., \& Tika, I.K 2005. Pengembangan Model dan Strategi Pembelajaran Fisika di Sekolah Menengah Umum untuk memperbaiki miskonsepsi siswa. Laporan Penelitian Hibah Bersaing. IKIP Negeri Singaraja.

Santyasa, I.W., Subratha, I.N, \& Suwindra, I.N.P.2003. Pembelajaran berbasis model rekonstruksi pengetahuan kognitif dan pengaruhnya terhadap hasil belajar. Laporan Penelitian. Research Grant program Due-Like Jurusan Pendidikan Fisika IKIP Negeri Singaraja. Lembaga Penelitian IKIP Negeri Singaraja.

Suwindra, I.N.P. 2004. Penerapan Model Pembelajaran Fisika Interaktif Berbasis Web di Kelas I SMU Negeri 1 Singaraja. Jurnal Pendidikan dan Pengajaran No 3 Th XXXVII Juli 2004 hal 85-95.

Sujanem, R., Pujani, N.M., \& Sutarno,E. 2004. Implementasi Pendekatan STML dalam Pembelajaran Fisika sebagai upaya Mengubah Miskonsepsi, Meningkatkan Literasi Sains dan Teknologi Siswa SMPN1 dan SMPN 6 Laporan Penelitian Program Due-Like. IKIP Negeri Singaraja.

Santyasa, I.W, Suwindra, I N.P, Rai Sujanem, Kade Suardana. 2005. Pengembangan Teks Fisika Bermuatan Model Perubahan Konseptual dan Komunitas Belajar Serta Pengaruhnya Terhadap Perolehan Kompetensi Siswa Kelas I Di SMU. Laporan Penelitian. RUKK Tahun I 2005.

Santoso, S. 2002. Buku Latihan SPSS Statistik multivariate. Jakarta: Gramedia.

Turner, S. V., \& Handler, M. G.1997. Hypermedia in education: Children as audience or authors? Journal of Information Technology for Teacher Education, 25-35.

William, D.C., Pedersen, S., \& Liu, M. 1998. An Evaluation of the Use of ProblemBased Learning Software By Middle School Students. Journal of Universal Komputer Science vol 4 issue 4 hal 466-483

Winer, B.J. 1971. Statistical Principles on experimental design, second edition. Tokyo: McGraw-Hill Kogakusha, Ltd.

Yulaelawaty, Ella. 2002. Karakteristik Pembelajaran MIPA Berdasarkan Kurikulum Berbasis 
Kompetensi.Makalah. Disajikan Pada Seminar Pembelajaran MIPA di FPMIPA IKIP Negeri Singaraja, Singaraja Bali tanggal 21 Desember 2002. 